The Scholar (July- December 2016) Islamic Creed - Relevance, Sources, and Chronology 40-55

\title{
ISLAMIC CREED - RELEVANCE, SOURCES, AND CHRONOLOGY
}

\author{
Basheer Ahme Dars* \\ Sohaib Ahmed Indhar** \\ DOI: $10.29370 /$ siarj/issue3ar11 \\ Link: https://doi.org/10.29370/siarj/issue3ar11
}

\begin{abstract}
:
Scholars of Islam have given high importance to the matter of Aqeedah and the acquisition of correct belief in the light of the book of Allah and the sunnah of His noble messenger and our master, Muhammad aلlughads. Learning the correct Aqeedah is even considered more important than learning any other aspects of religion in line with opinions of the Sahabah and the salaf. It is important to note, however, that though the concepts and underpinning objective related to Aqeedah existed from the time of companions and Tabi'oon, this term per se did not exist at that time. In the subsequent generations, a number of books were written on the subject which were categorized under various titles such as as-sunnah, altauheed, al-itiqad and others. In this article, the reasons that led to the writing of these esteemed books are discussed. We have also compiled a comprehensive, though not all encompassing, list of classical works on Aqeedah which can be very useful for the future researchers exploring this subject as well as the students of sacred knowledge who can utilize it in referring to these classical works and gaining comparative understanding of how the great Imams from the salaf understood the matter of Aqeedah, what challenges they faced in their times and what was their approach to counter that.
\end{abstract}

\footnotetext{
* Lecturer,MUET,SZAB Campus khairpur Mir's \& President Research Gateway Society,Paistan Email:bashirdars@muetkhp.edu.pk

${ }^{* *}$ M.Phil Scholar, Department of Comparative Religion \& Islamic Culture Email:sohaib_ahmed09@yahoo.com
} 
The Scholar (July- December 2016) Islamic Creed - Relevance, Sources, and Chronology 40-55

KEYWORDS: Islamic, Creed, Relevance, Sources, Chronology

WHAT IS AQEEDAH?

Sheikh Saleh Al-Munajjid explain that:

"Aqeedah refers to those matters which are believed, with certainty and conviction, in one's heart and soul. They are not tainted with any doubt or uncertainty"(al-Munajjid, 2013).

Therefore, Aqeedah are the matters of belief (which are known through Quran and Sunnah) that a Muslim must believe in the hearts without having any doubts (Sheikh Abu Zaid Zameer, 2009).

It is important to note, however, that heart is not where the Aqeedah ends, it is from where it starts (Ustadh Tim Humble, 2013). This means that it starts from the heart and has to go on to transform one's actions in accordance with one's beliefs. Sheikh Saleh Al-Munajjid explain scholars of Islam unanimously agree that the Iman and action go hand in hand. Iman consists of affirming the belief in the heart, declaring it by the tongue and demonstrating it by the actions (Al-Munajjid, 2004). In support of his claim about the unanimous agreement of the scholars and jurists about this, Sheikh Saleh Al-Munajjid has quoted a number of statements from the scholars which emphasize this aspect.

\section{ROOTS OF THE WORD 'AQEEDAH':}

The roots of the word 'Aqeedah' are 'Aqad (عقد)' (Sheikh Abu Zaid Zameer, 2009). This word has many similar meanings. It is generally used in terms of tying something. Its other meanings include 'to affirm', 'to be certain, 'to take oath' and 'to confirm'. The specific term 'Aqeedah' is used with regards to the matters of religion. The use of this word about a situation in which a person has certainty and affirmation in a worldly matter will not be considered as 'Aqeedah' in the Shariah terms.

The Shariah is divided into two parts; Beliefs and Actions. 
The Scholar (July- December 2016) Islamic Creed - Relevance, Sources, and Chronology 40-55

$\overline{\text { Beliefs (Aqaid - plural of 'Aqeedah') are issues, which are not related to }}$ how an act is performed, like belief in the Rububiyah (Lordship) of Allah, the obligation to worship Him (alone), and the belief in the rest of the aforementioned pillars of Iman. These are called Asliyah - the basic foundation.

Actions are issues related to how actions are performed like Salaat (prayer), Zakat (charity) and Sawm (fasting) and other rulings with regards to actions. These are termed as Far'eyyah - the branches because their soundness or corruption is based upon the beliefs.

Thus, the Correct Aqeedah (belief) is the foundation upon which the religion is based and with it, the actions are set aright" (QSEP, 2005).

With regards to conviction in heart about a religious matter, an Aqeedah can be correct or incorrect. Accordingly, in simple terms, the correct Aqeedah is only that which is from Quran and Saheeh Ahadith which are the absolute truth. The reason for the incorrect Aqeedah is Juhl (ignorance) and a lack of authentic religious knowledge. To counter that, we accordingly need to obtain what is missing i.e. the correct Islamic knowledge. This paper is a humble attempt to make our little contribution to this cause.

\section{SOURCES FOR AQEEDAH:}

Aqeedah is Tawqeefiyah ${ }^{1}$ - this means that the beliefs or the Aqeedah cannot be driven from anything except the Shariah proofs (Quran and Authentic hadith). There is no room for opinion and speculation in this regard. Why should we take Aqeedah only from Quran and Sunnah? Because no one is more knowledgeable about Allah and realities of everything more than Allah Himself. And after Allah, it is the messenger

\footnotetext{
1 'Tawqeefiyah' means that there is no room for opinion in it. No legislation or firm belief in this regard can come from any other source apart from the book of Allah and what is conveyed to us from His beloved messenger through authentic narrations. Whatever does not come from the Quran and Sunnah, cannot constituent Aqeedah and has to be rejected as an innovation.
} 
of Allah eall who knows the most about Him. These two sources have to be interpreted in a way that they were understood by the companions of

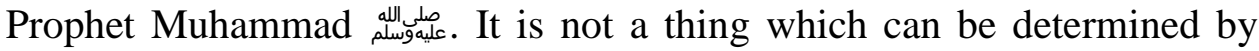
Ijtihad (Sheikh Abu Zaid Zameer, 2013) or anyone's opinion, considered or otherwise.(Sheikh Dr. Abdur-Rahman Dimashqiah, 2010)

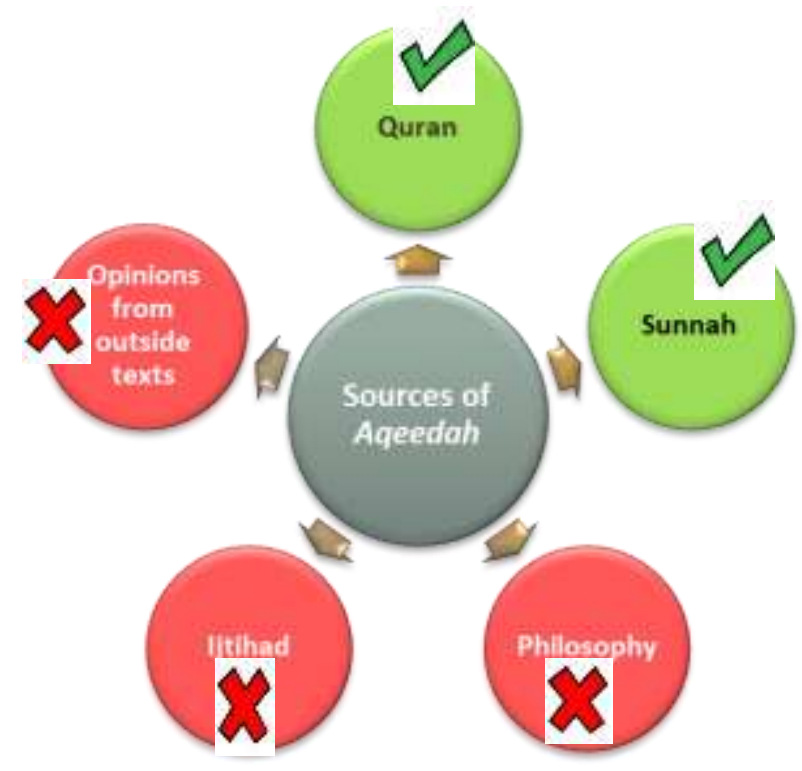

Figure 1: Sources for Aqeedah

Explanation for above mentioned points about sources for Aqeedah and their interpretation according to the way of companions, can be obtained from the following explanations by Imam Ibn Taymiyyah (Ibn Taymiyyah, 2002):

The first and the foremost thing which establishes who belong to Ahlus Sunnah Wal- Jama'ah and who do not is the methodology which is deployed to acquire the knowledge of the deen and the sources from which they get their beliefs, fiqh, and manners. The Ahlus Sunnah Wal Jama'ah's source is the book of Allah and the Sunnah of His messenger aلd allaghe No one's words and opinions can take precedence over the words and guidance from Allah and His messenger aلlughalle. Accordingly, the book and 
the Sunnah are the first point of reference for Ahlus Sunnah Wal Jama'ah for all their matters.

Accordingly to Ahl us-Sunnah, everyone can make errors in the matter of deen and otherwise except the most noble of men who was instructed by God Himself - Rasool Allah. Even the great scholars, mohaditheen, Imams and fuqaha are not free of errors being humans. Their opinions, accordingly, cannot be considered as absolute authority and can be accepted or rejected depending on their alignment with the book and the Sunnah. This principle has been consistently instructed by the noble Imams of our Ummah to accept their words if they are in alignment with sunnah and reject if they are not (Sh. Abdullah Hasan, 2012). It is only the messenger of Allah aلd wholle whose words Ahlus Sunnah accept with full conviction and without any doubt.

The Ahl us-Sunnah cling to the Sunnah of the beloved messenger

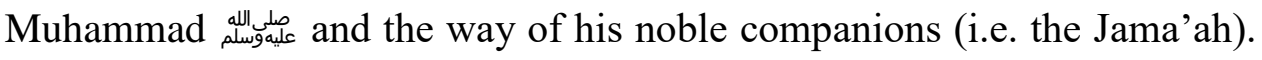
They follow what they did and follow those who followed them 2 .

Ahlus Sunnah attach themselves to the interpretations and understandings of Salaf us Saliheen3. They also take the interpretations of those who follow the pious predecessors. Their jama'ah is what they cling to in terms of principles and foundations. The reason for this is the fact the first Muslims (i.e. the Sahabah) learnt the matters of faith from the beloved messenger all and then taught it to the tabiuoon. In doing so they never preferred their own opinions, intellect or interpretations over those from the Messenger of Allah aلd challowed The salaf followed this methodology and communicated to us the pure belief.

\footnotetext{
${ }^{2}$ The virtue of Sahabah and those who follow them is evident from this hadith: "The best of my Ummah is my generation (Qarni), then those who follow them, then those who follow them." [Bukhari and Muslim]

${ }^{3}$ In line with hadith quoted in previous note, scholars have pointed out that the 'salaf' or the pious predecessors are the first three generations of Muslims. It also aligns with definition of the word 'qarni' in above hadith which can mean upto 100 years. According to this definition, the noble predecessors in the first 300 years from the time of prophet ele can be considered to be the salaf.
} 
The Scholar (July- December 2016) Islamic Creed - Relevance, Sources, and Chronology 40-55

The Ahlus Sunnah attach themselves to the Jama'ah of Rasool Allah and turn away from the places of separation and difference. They hold firmly to the rope on Allah, His book, the Sunnah and the Ijmaa (unanimous agreement of the companions). They refrain from diving into the realms of obscurity and un-clarity which separate and divide the united. This is because the Jama'ah in their estimation is the means of deliverance in this life and the hereafter.

\section{Importance of Studying Aqeedah:}

All the prophets came to teach us about the correct Aqeedah of tauheed and to connect the humanity to their Lord. Aqeedah is the basis of religion and this is what we understand from the shahadah - There is no God but Allah, He does not have any partner and Muhammad aلd ingale is his messenger. A person who believes in this testimony becomes a Muslim. If we do not understand this very statement, it leaves very little doubt that either our faith is very weak or it is not there at all. Accordingly, it is important to study this, acquire knowledge about this and the other matters of creed that stem from it. It is also important to understand what weakens our belief, and destroys it, so that we can continue to stay on the right path and follow the correct creed and belief (al-Fawzaan, 2015).

It is also important to understand that acceptance of good deeds is linked to the correct Aqeedah as it is mentioned in the glorious Quran:

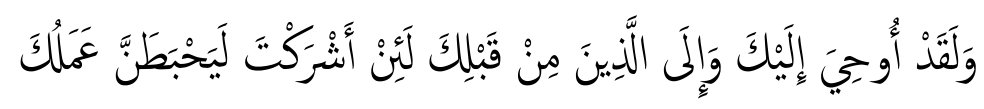

And it was already revealed to you and to those before you that if you should associate [anything] with Allah, your work would surely become worthless, and you would surely be among the losers.(Az-Zumar, 65)

In line with above, it is narrated from Imam Abu Hanifah that he said that understanding of the matters of belief comes before the understanding of shariah (Al-Qari, 2013). Sheikh ul Islam Al-Haruwi Al-Ansari emphasized the same point in his book Itiqad Ahlus Sunnah that the first obligation on a believer is to learn about Allah and the matters of belief. Once people 
acquire the belief, they can then be informed about matters of shariah such as prayers etc ${ }^{4}$. Imam Ibn Taymiyyah explain in his book Aqeedah AlWastiyyah that what distinguishes the true Ahlus Sunnah Wal-Jama'ah from others is their belief and this is what makes them Al-Firqah AnNajiyyah Al-Mansoorah (the saved sect) ${ }^{5}$.

It becomes clear from this that if we have deviation in our belief, our deeds will not be accepted. Accordingly, it is extremely vital, then, to understand what correct Aqeedah is, so that we can cling on to it and prevent ourselves from falling into the deviations. Scholars of Islam have always emphasized the importance of Aqeedah (al-Fawzaan, 2015) and communicated to us its pure form through their esteemed writings.

\section{Historical Overview of Teaching and Learning of Aqeedah:}

Glassé and Huston (2003) explained that in order to refute the heresies, deviations and incorrect point of views, scholars of Islam presented systematic statements to differentiate right from wrong in a clear manner in the light of Quran and Sunnah. These systematic statements were known by various names such as Al-Tawheed, As-Sunnah, Al-Shariah, AL-Itiqad and others (Al-Qari, 2013). In the present age as well, these statements illuminate for us the correct creed and highlight the deviations that can lead us astray.

Following is a brief account on how the matter of creed and Aqeedah was transmitted through the earlier generations of Muslims.

\footnotetext{
${ }^{4}$ It is in accordance with the saying of Jundub ibn Abdullah R.A. in which he is reported

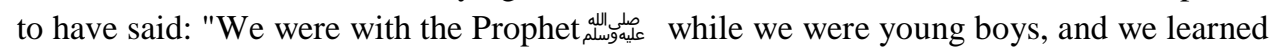
Iman before we learned the Quran. And then we learned the Quran and it increased us in Iman." (Reported by Ibn Majah and authenticated by Al-Albani - May Allah be pleased with them)

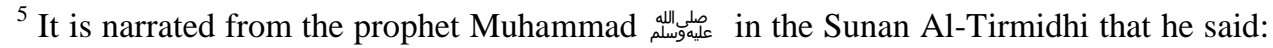
"The Jews split up into seventy-one sects, the Christians split up into seventy-two sects, and this ummah (Muslims) will split up into seventy-three sects; all of them are in the Fire except one." Someone asked: "which is that one O Messenger of Allah?". He replied: "Whoever is upon that which I am upon and my companions". The hadith has been categorized by scholars as Hasan.
} 


\section{Sahabah:}

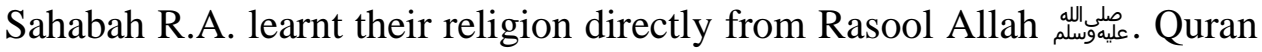
was revealed in front of their eyes. Allah provided them with a number of opportunities to acquire the correct faith. We know how angel Gabriel came and taught them the matters of faith through a conversation with Rasool Allah. Whenever they needed guidance about anything, they could go directly to the Messenger of Allah and take it. Accordingly, they were perfect in their faith and were free from all forms of doubts and confusion in the matter of Aqeedah. There Aqeedah was purely from the Quran and the sunnah. Accordingly, there was no need for any other book except the Quran and collection of the noble words of the messenger of Allah ${ }^{6}$ (alFawzaan, 2015).

It is also important to note that as the Prophet aلd halle himself explained the words of the Quran and their meaning to his companions, this gave them a great advantage over all those who came after them with regard to the interpretation of the Quran and the Sunnah. No one could know the meaning of the Quran and Sunnah better than they did. So whenever a dispute arises about the meaning of a hadith or a verse from the Quran, then we have to go back to the understanding of companions regarding that. This will close the way to those who misinterpret Quran and the Sunnah without knowledge basing it on their false desires. (Sheikh Dr. Abdur-Rahman Dimashqiah, 2010)

Two of the prominent examples of incorrect interpretations which still exists in our times, and clearly go against the interpretations of companions, are the philosophies of Khwarij and Rawafidh, who commit all forms of atrocities due to their misguidance and utter ignorance while considering it to be guidance or knowledge, coupled with their materialistic, political and social agendas (May Allah guide us all and protect from misguidance).

\footnotetext{
${ }^{6}$ Research suggests some early compilations of hadith being attributed to the companions
} such as Abdullah Ibn Amr'. (Albayrak, 2015) 


\section{Tabi'een:}

The students of companions proceeded upon this manhaj and approach the Tabi'een (the next generation after the Companions). Accordingly, this generation was also free from doubt (al-Fawzaan, 2015). Till this generation, the concept of 'Aqeedah' per se did not formally exist (Shaykh Akram Nadwi, 2013) and sources for all beliefs were the book of Allah

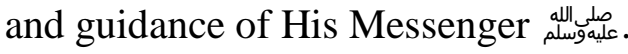

\section{Later Generations and Rise of sects:}

After the generation of Taibi'een, many people entered Islam who did not have the matters of Aqeedah firmly grounded in their hearts and they were accordingly prone to deviations ${ }^{7}$. Deviant philosophies and ways of thinking also started in infiltrate into the matters of belief. A number of deviant sects accordingly rose which did not take their belief from the Quran and Sunnah but claimed that they did. There were also some other sects that emerged based on their misinterpretation of the texts. Such misinterpretations were rooted in their deviation from the understanding that the companions and the tabi'een had about the Quran and Sunnah.

In such times, the great Imams of Islam, the salaf as-saliheen, took the responsibility to clearly lay out the important matters of creed in the light of Quran and sunnah so that such explanations could become a reference point for their as well as the future generations. The noble Imams accordingly wrote various books on Aqeedah and destroyed the deviant beliefs. It is this reason that we see mention of certain deviant sects in these classical texts with an explanation of where they had deviated from the straight path.

This is how Allah SWT gave us protection and sent people who reformed the ummah and guided them to the straight path. Those trustworthy

\footnotetext{
7 This is in accordance with a statement from Umar R.A., as mentioned in Ibn Taymiyah's Majmua Al-Fatawa (10/301), where he is reported as saying: "Soon the bonds of Islam will be loosened bit by bit, because people will enter into Islam but will be unaware of Jahiliyah (ignorant practices that Islam opposes)."
} 
The Scholar (July- December 2016) Islamic Creed - Relevance, Sources, and Chronology 40-55 carriers transmitted the religion to us as it was conveyed by the messenger of Allah and dissolved the misinterpretations and incorrect beliefs.

The early texts on Aqeedah were known from various names. One of the common names for such works was Kutub As-Sunnah (books of the Sunnah) (al-Fawzaan, 2015).

Following is an overview of some of the classical works on Aqeedah:

TABLE 1: Chronology of Classical Texts on Aqeedah

Note: This is not an all-inclusive list.

\begin{tabular}{|c|c|c|}
\hline Book & Author & Era \\
\hline Fiqh Al-Akbar & Imam Abu Hanfiah & d. $150 \mathrm{H}$ \\
\hline $\begin{array}{lll}\text { Itiqad } & \text { Aimah } & \text { Al- } \\
\text { Hadith } & & \end{array}$ & Imam Sufyan Al-Thauri & d. $161 \mathrm{H}$ \\
\hline Kitabul Iman & $\begin{array}{l}\text { Abu 'Ubayd al-Qaasim ibn } \\
\text { Salaam }\end{array}$ & d. $224 \mathrm{H}$ \\
\hline Kitabul Iman & Imam Ib Abee Shaybah & $\mathrm{d} .235 \mathrm{H}$ \\
\hline $\begin{array}{l}\text { Usool us -Sunnah, } \\
\text { Ar-Radd 'al al- } \\
\text { Jahmiyyah wa } \\
\text { Al-Zanaadaqah }\end{array}$ & Imam Ahmed Ibn Hanbal & d. $241 \mathrm{H}$ \\
\hline $\begin{array}{l}\text { Khalq Afaalul-Ibaad, } \\
\text { Kitabul-Imaan, } \\
\text { Kitab Al-Tawheed }\end{array}$ & Imam Bukhari & d. $256 \mathrm{H}$ \\
\hline Aqeedah Ar-Raziyan & $\begin{array}{l}\text { Imam Abu Zur'ah Al-Razi } \\
\text { Imam Abu Hatem Al-Razi }\end{array}$ & $\begin{array}{l}\text { d. } 264 \\
\text { d. } 273\end{array}$ \\
\hline As-Sunnah & Abu Bakr al-Athram & $\mathrm{d} .273 \mathrm{H}$ \\
\hline
\end{tabular}


The Scholar (July- December 2016) Islamic Creed - Relevance, Sources, and Chronology 40-55

\begin{tabular}{|c|c|c|}
\hline Book & Author & Era \\
\hline Kitab us Sunnah & $\begin{array}{l}\text { Imam Ibn Abu Dawud As- } \\
\text { Sijistani }\end{array}$ & d. $275 \mathrm{H}$ \\
\hline $\begin{array}{l}\text { Al-Ikhtilaf fi Ladfh } \\
\text { war-Rad 'ala Al- } \\
\text { Jahmiyah }\end{array}$ & Imam Ibn Qutaybah & d. $276 \mathrm{H}$ \\
\hline Asl us-Sunnah & Imam Abu Hatim ar-Razi & d. $277 \mathrm{H}$ \\
\hline $\begin{array}{l}\text { Ar-Rad 'ala Al- } \\
\text { Jayhmiyyah }\end{array}$ & Imam ad-Daarimee & d. $280 \mathrm{H}$ \\
\hline As-Sunnah & Qadhi Ibn Abee 'Asim & d. $287 \mathrm{H}$ \\
\hline As-Sunnah & $\begin{array}{l}\text { Hafidh Abdullah ibn Imam } \\
\text { Ahmad }\end{array}$ & d. $290 \mathrm{H}$ \\
\hline As-Sunnah & $\begin{array}{l}\text { Muhaddith AbuBakr al- } \\
\text { Maroozee }\end{array}$ & d.292H \\
\hline As-Sunnah & Al-Marwazi & d. $292 \mathrm{H}$ \\
\hline Sharh As-Sunnah & Imam Ibn Jarir at-Tabari & d. $310 \mathrm{H}$ \\
\hline $\begin{array}{l}\text { Kitab Al-Tawheed Wa } \\
\text { Ithbaat Sifat Al-Rabb }\end{array}$ & Imam Ibn Khuzaymah & d. $311 \mathrm{H}$ \\
\hline $\begin{array}{ll}\text { Aqeedah } & \text { At- } \\
\text { Tahaawiyyah } & \end{array}$ & Imam Abu Jafar at-Tahawi & d. $321 \mathrm{H}$ \\
\hline $\begin{array}{l}\text { Al-Maqaalatul- } \\
\text { Islamiyeen, } \\
\text { Ar-Risaalah ilaa Ahlth- } \\
\text { Thaghr and } \\
\text { Al-Ibaanah 'an } \\
\text { Usoolid-Diyaanah }\end{array}$ & Imam Abul-Hasan al-Ashari & d. $324 \mathrm{H}$ \\
\hline Sharhus-Sunnah & Imam al-Barbahari & d. $329 \mathrm{H}$ \\
\hline
\end{tabular}


The Scholar (July- December 2016) Islamic Creed - Relevance, Sources, and Chronology 40-55

\begin{tabular}{|c|c|c|}
\hline Book & Author & Era \\
\hline $\begin{array}{l}\text { Ta'weelaat Ahl is- } \\
\text { Sunnah, } \\
\text { Kitab ut-Tawheed }\end{array}$ & Abu Mansur al-Maturidi & d. $333 \mathrm{H}$ \\
\hline Kitab us-Sunnah & Qadhi Abu Ahmad al-Asaal & d. $349 \mathrm{H}$ \\
\hline Ash-Shareeah & Imam Abu Bakr al-Aajuri & d. $360 \mathrm{H}$ \\
\hline $\begin{array}{l}\text { Itiqaad Aimatul- } \\
\text { Hadeeth }\end{array}$ & Imam Abu Bakr al-Ismaeeli & d. $371 \mathrm{H}$ \\
\hline $\begin{array}{l}\text { Kitab Al-Sifaat, } \\
\text { Kitab Al-Nuzool }\end{array}$ & Imam ad-Daaraqutni & d. $385 \mathrm{H}$ \\
\hline $\begin{array}{l}\text { Al-Ibanah 'an } \\
\text { Sharee'atil Firqatin - } \\
\text { Naajiyah and Sharhul- } \\
\text { Ibanah 'an Usoolis- } \\
\text { Sunnah wad-Diyanah }\end{array}$ & Imam Battah al-Akbari & d. $387 \mathrm{H}$ \\
\hline As-Sunnah & Imam Abu Bakr ibn Abi Asim & d. $387 \mathrm{H}$ \\
\hline $\begin{array}{l}\text { Muqaddimah Al- } \\
\text { Risalaah }\end{array}$ & $\begin{array}{l}\text { Imam Abu Muhammad } \\
\text { Abdullah Ibn Abi Zayd al- } \\
\text { Qayrawani }\end{array}$ & d. $389 \mathrm{H}$ \\
\hline $\begin{array}{l}\text { Kitab Al-Tawheed, } \\
\text { Ar-Rad 'ala Al- } \\
\text { Jahmiyyah }\end{array}$ & Imam Ibn Mandah & d. $395 \mathrm{H}$ \\
\hline al-Tamhid & $\begin{array}{l}\text { Muhạmmad ibn al-Ṭayyib al- } \\
\text { Bāqillān̄̄ }\end{array}$ & d. $403 \mathrm{H}$ \\
\hline al-Mujarrad & Ibn Furak & d. $406 \mathrm{H}$ \\
\hline $\begin{array}{l}\text { Sharh Usool Itiqaad } \\
\text { Ahlus-Sunnah Wal } \\
\text { Jama'ah }\end{array}$ & Imam al-Laalilkaa'ee & d. $428 \mathrm{H}$ \\
\hline
\end{tabular}


The Scholar (July- December 2016) Islamic Creed - Relevance, Sources, and Chronology 40-55

\begin{tabular}{|c|c|c|}
\hline Book & Author & Era \\
\hline $\begin{array}{l}\text { Al-Wusul ila al- } \\
\text { Marifah Al-Istiwa }\end{array}$ & $\begin{array}{l}\text { Imam Abu 'Amr at-Talamanki } \\
\text { al-Andalusi }\end{array}$ & $\mathrm{d} .429 \mathrm{H}$ \\
\hline Al-Itiqad & Abu Nuaym al-Ashbaanee & $\mathrm{d} .430 \mathrm{H}$ \\
\hline $\begin{array}{lll}\text { Risalah fee } & \text { Ithbatil- } \\
\text { Istiwaa } & & \end{array}$ & $\begin{array}{l}\text { Imam Abu Muhammad al- } \\
\text { Juwayni }\end{array}$ & d. $438 \mathrm{H}$ \\
\hline Kitab Al-Irshad & $\begin{array}{l}\text { Imam Abu Muhammad al- } \\
\text { Juwayni }\end{array}$ & $\mathrm{d} .438 \mathrm{H}$ \\
\hline Aqeedah Nizamiyyah & $\begin{array}{l}\text { Imam Abu Muhammad al- } \\
\text { Juwayni }\end{array}$ & $\mathrm{d} .438 \mathrm{H}$ \\
\hline $\begin{array}{l}\text { Aqidatus-Salaf } \\
\text { Ashaabul-Hadeeth }\end{array}$ & $\begin{array}{l}\text { Imam Abu Uthmaan as- } \\
\text { Sabooni }\end{array}$ & d. $449 \mathrm{H}$ \\
\hline $\begin{array}{l}\text { Al-I'tqad alaa Madhab } \\
\text { As-Salaf Ahlus-Sunnah } \\
\text { wal-Jama'ah }\end{array}$ & Imam al-Bayhaaqi & $\mathrm{d} .457 \mathrm{H}$ \\
\hline Kitab al-Iman & AL-QADI ABU YA'LA & d. $458 \mathrm{H}$ \\
\hline Dhamul-Kalam & $\begin{array}{l}\text { Shaykh ul-Islaam Abu } \\
\text { Ismaeel al-Harawi }\end{array}$ & $\mathrm{d} .481 \mathrm{H}$ \\
\hline Qawaid al-Aqaid & Imam Ghazali & d. $505 \mathrm{H}$ \\
\hline Umdat al-Aqidah & $\begin{array}{l}\text { Imam Abu Hafs Umar an- } \\
\text { Nasafi }\end{array}$ & d. $537 \mathrm{H}$ \\
\hline Bad' al-Amali & $\begin{array}{l}\text { Ali bin Uthman al-Ushi Al- } \\
\text { Maturidi }\end{array}$ & d. $569 \mathrm{H}$ \\
\hline Lum'at ul-'Itiqad & Imam Ibn Qudhama & d. $620 \mathrm{H}$ \\
\hline Tawali' al-Anwar & $\begin{array}{l}\text { Abdallah ibn Omar al- } \\
\text { Baidawi }\end{array}$ & d. $685 \mathrm{H}$ \\
\hline $\begin{array}{l}\text { Aqeedah Ahlus Sunnah } \\
\text { Wal Jama'ah }\end{array}$ & Akmal ud Din Al-Babarti & d. $712 \mathrm{H}$ \\
\hline
\end{tabular}


The Scholar (July- December 2016) Islamic Creed - Relevance, Sources, and Chronology 40-55

\begin{tabular}{|ll|l|l|}
\hline \hline Book & & Author & Era \\
\hline $\begin{array}{l}\text { Al-Aqidah } \\
\text { Wasitiyah }\end{array}$ & Al- & Ibn Taymiyah & $\mathrm{d} .728 \mathrm{H}$ \\
\hline $\begin{array}{l}\text { Al-Aqidah } \\
\text { Hamawiyah }\end{array}$ & Al- & Ibn Taymiyah & $\mathrm{d} .728 \mathrm{H}$ \\
\hline Kitab Al-Iman & Ibn Taymiyah & $\mathrm{d} .728 \mathrm{H}$ \\
\hline Al-Uloow & Shams ad-Din al-Dhahabi & $\mathrm{d} .748 \mathrm{H}$ \\
\hline $\begin{array}{l}\text { Al-'Aqidah } \\
\text { Sanusiyah }\end{array}$ & Al- & $\begin{array}{l}\text { Muhammad ibn Yusuf al- } \\
\text { Sanusi }\end{array}$ & $\mathrm{d} .795 \mathrm{H}$ \\
\hline
\end{tabular}

\section{Present State:}

When we critically analyse the deviant sects of today's age and their system of beliefs, it becomes evident that they have inherited a great deal from the deviant sects from the past (Qari Muhammad Tayyib Qasimi, 2005).

In present age, we not only see remains of some previous attempted distortions, but also new philosophies that have emerged with an aim to sow the seeds of doubt and confusion among the Ummah. Works on creed are accordingly of continued importance in the present age as they were in the past times in order to keep the Muslims steadfast on the very tenants of their faith. We also need to study the reasons which result in such misguidances, so that we can avoid them and keep our belief correct and pure. Referring back to the explanation of Aqeedah by the Imams of Ahlus Sunnah wal Jama'ah, we will be better equipped to not only keep ourselves on the straight path but also answer and assist those who have gone astray due to the mis-interpretations and flawed understanding. That only is what can rescue us in this downpour for fitnahs and batil beliefs (Qari Muhammad Tayyib Qasimi, 2005).

\section{Conclusion:}


The Scholar (July- December 2016) Islamic Creed - Relevance, Sources, and Chronology 40-55

It is evident from the discussion in this paper and that the books of Aqeedah were compiled as a response to the heresies and deviations that started to surface during the time of salaf and afterwards. The pious predecessors penned down the specific aspects of belief and faith that was essential for all Muslims to understand, affirm and acknowledge. They also segregated the deviant ideologies and concepts by warning the believers about their causes and why they considered them against the Quran and Sunnah. Interestingly, despite the fact that centuries have passed since these books were written, they relevance has not diminished and we still see a common trend between the deviations of that time and today's age. We still have the Khwarij, Rawafidh, Qadyanis, Reformists and other deviant groups and sects in our times. The reasons for their deviation are no different from what their ancestors in deviation had. Accordingly, it is more important for us than ever before, to dive deep into the learning of our beautiful religion and prepare ourselves against these fitnahs. Aqeedah, along with other core Islamic sciences such as Usul AlFiqh, Usul Al-Hadith and Usul Al-Tafsir, is unparalleled in importance in current times. The classical books on Aqeedah still serve as our lighthouse and take us to our destination by preventing the misguidance that keeps on chasing us in various shapes and forms. Comparative study of these texts and deep reflection on the present age and times can help us strengthen our faith and connect to the bigger picture.

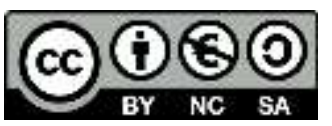

This work is licensed under a Creative Commons Attribution-NonCommercial-ShareAlike 4.0 International (CC BY-NC-SA 4.0) 


\section{REFERENCES:}

al-Fawzaan, S. S. (2015). Aqeedah (creed and belief) is the foundation of the religion. Retrieved December 27, 2015, from http://salaf-us-saalih.com/2015/05/22/aqeedah-creedand-belief-is-the-foundation-of-the-religion/ al-Munajjid, S. M. S. (2013). What is 'Aqeedah? Retrieved December 27, 2015, from https://islamqa.info/en/951

Albayrak, İ. (2015). Mastering Knowledge in Modern Times. Işık Yayınc1lık Ticaret. Al-Munajjid, M. S. (2004). Islamic 'aqeedah is a practical method; and important books on 'aqeedah - islamqa.info. Retrieved July 17, 2016, from https://islamqa.info/en/59911 Al-Qari, A. A. (2013). Aqeedah, Its Meaning and Importance. Retrieved July 16, 2016, from http://www.iisna.com/articles/aqeedah/aqeedah-its-meaning-and-importance/ Glassé, C., \& Smith, H. (2003). The New Encyclopedia of Islam. Rowman Altamira. Ibn Taymiyyah. (2002). More Principles of Aqeedah from Shaikh ul-Islaam Ibn Taymiyyah. Salafi Publications. Retrieved from http://www.salafipublications.com/sps/sp.cfm?subsecID=AQD02\&articleID=AQD02000 $3 \&$ articlePages $=1$

Qari Muhammad Tayyib Qasimi. (2005). Aqeedatul Tahawi. South Africa: Mufti Afzal Hosein Elias. Retrieved from https://attahawi.files.wordpress.com/2009/12/aqeedatutahawi.pdf

QSEP. (2005). The Meaning of al-Aqeedah and its importance. As-Sunnah (Vol. 2 Issue No. 5). Retrieved from http://qsep.com/modules.php?name=assunnah\&d_op=viewarticle\&aid=89 Sh. Abdullah Hasan. (2012). Understanding the Statements of the Illustrious Imams: 'When a Hadith is Sahih it is my Madhab". Retrieved July 17, 2016, from http://muslimmatters.org/2012/12/04/maqasid-al-shariah/ Shaykh Akram Nadwi. (2013). What is the right Aqeedah? UK: Nadwi Foundation. Retrieved from https://www.youtube.com/watch?v=A7gA-SAXN-g Sheikh Abu Zaid Zameer. (2009). Saheeh Aqeedah ki ahmiyat - Dars 1 of 4. India: Islamic Lecture Dot Net. Retrieved from https://www.youtube.com/watch?v=2FrthWt2zuk Sheikh Abu Zaid Zameer. (2013). Fiqh ke baaz usool Course. India: Islamic Lecture Dot Net. Retrieved from https://www.youtube.com/playlist?list=PLgpPOIQ2eEw1gWK6vsiS6LQjvLNDx2731 Sheikh Dr. Abdur-Rahman Dimashqiah. (2010). Course in Aqeedah. Qatar: Qatar Islamic Cultural Centre. Retrieved from http://www.fanar.gov.qa/Publication/CourseInAqeedah.pdf Ustadh Tim Humble. (2013). ARE AQEEDAH AND IMAN ONLY IN THE HEART? UK: Digital Minber. Retrieved from https://www.youtube.com/watch?v=WVlQjTfPZZg 